\title{
Sistem Informasi Geografis Pemetaan Daerah Hama Wereng pada Tanaman Padi Berbasis Android dengan Google Maps API, di Kabupaten Banyumas
}

\author{
Geographic Information System for Planthoppers Mapping on Rice Plant \\ Based on Android with Google Maps API, in Banyumas Regency
}

\author{
Lukni Maulana ${ }^{1}$, Harjono $^{2}$, Maulida Ayu Fitriani ${ }^{3}$ \\ ${ }^{1,2,3}$ Teknik Informatika, Fakultas Teknik dan Sains, \\ Universitas Muhammadiyah Purwokerto \\ 1ukni94@gmail.com
}

\begin{abstract}
ABSTRAK
Pengembangan produksi padi pada sektor pertanian dewasa ini terus ditingkatkan karena padi merupakan makanan pokok khususnya bagi mayoritas penduduk Banyumas, selain itu pada sektor produksi padi ini juga turut menyumbang pemasukan pendapatan daerah di Kabupaten Banyumas, dalam usaha peningkatan produktivitas hasil panen padi banyak ditemui kendala-kendala di lapangan, salah satu kendala yang dihadapi adalah adanya serangan hama wereng yang menyerang banyak lahan pertanian di wilayah Kabupaten Banyumas. Oleh karena itu untuk membantu dan mengatasi dalam peningkatan produktivitas hasil panen padi, dibuatlah sebuat Sistem Informasi Geografis untuk pemetaan hama wereng di daerah Kabupatean Banyumas. Tujuan dari penelitian adalah membangun sebuah Sistem Informasi Geografis pemetaan serangan hama wereng pada tanaman padi yang berada di wilayah Kabupaten Banyumas berbasis aplikasi Android dengan Google Maps API. Metode penelitian yang digunakan adalah menggunakan model waterfall meliputi tahap requirement definition, system and software design, implementation and unit testing, integration and system testing, dan operation and maintenance. Aplikasi ini memberikan kemudahan bagi para petani untuk mengetahui informasi tentang hama tanaman seperti wereng dan cara penanganannya, memudahkan bagi para petugas dari Dinas terkait dalam memperbaharui informasi seputar hama wereng, serta dapat mengetahui informasi pemetaan penyebaran hama wereng pada tanaman padi di Banyumas dengan sistem ini.
\end{abstract}

Kata kunci: Sistem Informasi Geografis, Hama Wereng, Google Maps API

\begin{abstract}
Nowadays, the development of rice production in the agricultural sector is continued to be improved because rice is the staple food, especially for the majority of Banyumas residents. Besides, this rice production sector also contributes to the income of local revenue in Banyumas Regency. There are many obstacles encountered during the attempt to increase the productivity of the rice harvest. One of them is planthopper pests that attack a lot of agricultural land in Banyumas Regency. Therefore, to overcome the problem and increase the rice harvest's productivity, the Geographic Information System is made to help do the planthoppers pest mapping in Banyumas Regency. This research aimed to develop a Geographic Information System of planthoppers pest attack in rice in Banyumas Regency based on Android application using Google Maps API. The method used in this research is the waterfall model, including the stages of requirement definition, system and software
\end{abstract}


design, implementation and unit testing, integration and system testing, as well as operation and maintenance. This application provides convenience for the farmers to know the information about pests such as planthoppers and the way to handle them, makes it easy for the officials of relevant Department to update the information about planthoppers, as well as to find out the spread of planthoppers in rice plant in Banyumas using this system.

Keywords: Geographic Information System, Planthoppers, Google Maps API

\section{PENDAHULUAN}

Pengembangan produksi padi pada sektor pertanian dewasa ini terus ditingkatkan karena padi merupakan makanan pokok khususnya bagi mayoritas penduduk Banyumas, selain itu pada sektor produksi padi ini juga turut menyumbang pemasukan pendapatan daerah di Kabupaten Banyumas, dalam usaha peningkatan produktivitas hasil panen padi banyak ditemui kendala-kendala, salah satu kendala yang dihadapi adalah adanya serangan hama wereng yang menyerang banyak lahan pertanian wilayah Kabupaten Banyumas. Hama wereng merupakan salah satu hama pada tanaman padi dengan resiko serangan yang harus diperhitungkan dalam setiap budidaya tanaman padi, karena tingkat serangannya yang selalu dominan pada setiap musim tanam padi. Oleh karena itu untuk membantu dan mengatasi dalam peningkatan produktivitas hasil panen padi di Kabupaten Banyumas, dibuatlah sebuah Sistem Informasi Geografis pemetaan serangan hama wereng pada tanaman padi yang berada di wilayah Kabupaten Banyumas berbasis aplikasi Android dengan Google Maps API. Sistem Informasi Geografis adalah kumpulan yang terorganisir dari perangkat keras komputer, perangkat lunak, data geografis, metode, dan personil yang dirancang secara efisien untuk memperoleh, menyimpan, memperbaharui, memanipulasi, menganalisa, dan menampilkan bentuk informasi yang bereferensi geografis (Riyanto, 2010).

Hama tanaman dalam arti luas adalah semua organisme atau binatang yang karena aktivitas hidupnya merusak tanaman sehingga menimbulkan kerugian ekonomi bagi manusia. Seluruh ataupun sebagian tanaman yang terserang hama dapat mengalami penurunan fungsi atau bahkan tidak berfungsi sama sekali proses metabolisme (fisiologis) pada tubuh tanaman tersebut, sehingga pertumbuhannya tidak normal dan bahkan berakhir dengan kematian tanaman (Rukmana \& UU Sugandi, 1997). Adapun jenis-jenis hama wereng yang menyerang pada tanaman padi diantaranya adalah sebagai berikut: (a) Wereng Coklat (Nilaparvata lugens) Imago wereng coklat mempunyai dua bentuk sayap, yaitu yang bersayap panjang (dapat terbang) dan bersayap pendek (tidak dapat terbang). Kedua bentuk ini dapat saling bergantian tergantung populasi dan ketersediaan makanan. Bila populasi padat dan makanan kurang akan terbentuk imago yang bersayap panjang pada generasi berikutnya. Sebaliknya bila makanan cukup akan terbentuk imago bersayap pendek. (b) Wereng Hijau (Nephotettix nigropictus dan N. virescens), ada beberapa jenis seperti Nephotettix nigropictus, Imago berwarna hijau daun dengan panjang tubuh 4-6 mm. sayap depan memiliki bercak hitam. Imago bersifat aktif dan menyenangi cahaya. Nephotettix virescens, Imago berwarna hijau dan berukuran panjang 4-6 $\mathrm{mm}$. sayapnya memiliki bercak hitam. Wereng hijau selain dapat menyebabkan kerusakan secara langsung pada tanaman, juga dapat membawa penyakit virus tungro. Gejala serangan hama ini dapat diketahui dari adanya sejumlah kulit nimfa pada daun padi (Soemadi, 1997).

Goole telah menyediakan layanan bagi para developer aplikasi android untuk menggunakan API Google Map pada aplikasi mereka. API sendiri adalah kepanjangan Application Programming Interface. Selain itu, dokumentasi dan forum yang membahas penggunaan API Google Map pada aplikasi android juga tersedia banyak di situs developer 
android. Ada dua macam penggunaan API Google Map, yaitu API Google Map standar dan API Google Map untuk bisnis (Agung, 2015).

Tujuan dari penelitian ini adalah untuk membangun sebuah Sistem Informasi Geografis pemetaan daerah penyebaran hama wereng pada tanaman padi berbasis Android dengan Google Maps API. Manfaat dari penelitian ini adalah memberi informasi penyebaran atau populasi wereng di Kabupaten Banyumas pada saat penelitian, Lembaga atau Dinas yang terkait dapat mengetahui informasi pemetaan penyebaran hama wereng pada tanaman padi di Kabupaten Banyumas, memberikan kemudahan bagi para petani untuk mengetahui informasi tentang hama tanaman seperti wereng dan cara penanganannya, dan memberikan kemudahan bagi para petugas dari Dinas terkait untuk memperbaharui informasi seputar hama wereng menggunakan sistem ini. Dengan demikian, sistem yang berbasis Android ini diharapkan mampu menjadi solusi dan memudahkan bagi para petani dan petugas penyuluh lapangan khususnya di wilayah Kabupaten Banyumas untuk lebih mengetahui tentang daerah penyebaran hama wereng pada tanaman padi dan cara penanganannya.

\section{METODE}

\section{Pengumpulan Data}

Metode pengumpulan data adalah cara yang digunakan oleh peneliti dalam mengumpulkan data penelitiannya (Mustafidah \& Suwarsito, 2020). Contoh variasi metode pengumpulan ialah angket, wawancara, pengamatan atau observasi, tes, dan dokumentasi. Metode pengumpulan data yang digunakan dalam penelitian adalah interviu dan dokumentasi.

Interviu yang biasa disebut dengan wawancara atau kuesioner lisan adalah sebuah dialog yang dilakukan pewawancara untuk memperoleh informasi dari terwawancara. Interviu digunakan peneliti untuk menilai keadaan seseorang, misalnya untuk mencari data tentang variabel latar belakang murid, orang tua, pendidikan dan sikap terhadap sesuatu (Mustafidah \& Suwarsito, 2020). Dalam penelitian ini, interviu dilakukan dengan konsultasi langsung kepada petugas penyuluh pertanian di Laboratorium Pengamatan Hama dan Penyakit Tanaman Banyumas dengan Bapak Arif. Wawancara tersebut menghasilkan data rincian detail jumlah luas tambah, keadaan, sebaran, dan pengendalian organisme pengganggu tanaman di wilayah Banyumas.

Dokumentasi berasal dari kata dokumen yang artinya barang-barang tertulis. Di dalam melaksanakan metode dokumentasi, peneliti menyelidiki benda-benda tertulis seperti buku, majalah, catatan harian dan sebagainya (Mustafidah \& Suwarsito, 2020). Pengumpulan data dilakukan dengan cara mencari data yang sudah ada langsung di Kantor Laboratorium Pengamatan Hama dan Penyakit Tanaman Banyumas (Lab PHP Banyumas) serta di kantor Badan Penyuluh Pertanian (BPP) di setiap Kecamatan yang dijadikan sebagai lokasi sampel pengambilan data diantaranya Kecamatan Wangon, Jatilawang, Sumpiuh, Tambak, Sokaraja, Kembaran, Baturaden, Sumbang, Ajibarang, dan Cilongok. Selain itu pengumpulan data dengan menggunakan metode dokumentasi berupa data latitude (Garis Lintang) dan longitude (Garis Bujur) yang diperoleh dengan menggunakan layanan lokasi peta online dari Google Maps.

\section{Model Pengembangan Sistem}

Model yang digunakan dalam pengembangan sistem ini adalah dengan menggunakan model waterfall. Dalam model pengembangan sistem terdapat tahapan utama dari waterfall model yang langsung mencerminkan aktifitas pengembangan dasar. Terdapat 5 tahapan pada waterfall model yaitu requirement definition, system and software design, implementation and unit testing, integration and system testing, dan operation and maintenance. Tahapan dari model waterfall ini ditunjukkan pada Gambar 1. 


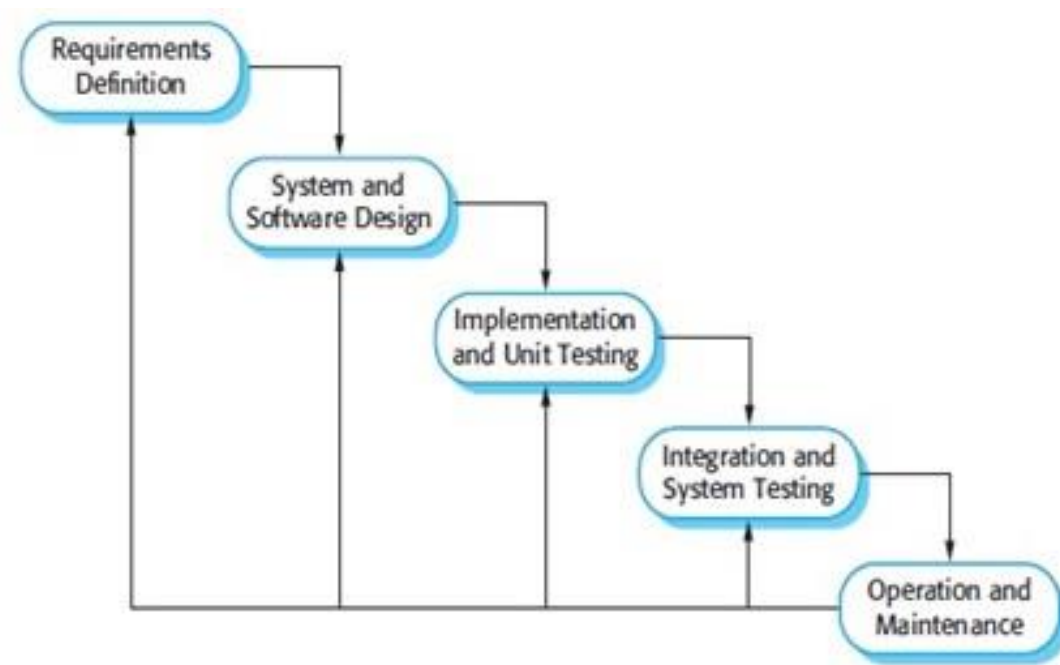

Gambar 1. Waterfall Model (Sommerville, 2011)

Berikut adalah penjelasan dari tahapan-tahapan waterfall model:

- $\quad$ Requirements Definition

Tahapan ini dilakukan identifikasi masalah, pengumpulan data yang diperlukan dalam pembuatan sistem. Penetapan fitur aplikasi, kendala dan tujuan dari sistem. Semua hal tersebut akan diterapkan secara rinci dan berfungsi sebagai spesifikasi sistem.

- $\quad$ System and Software Design

Tahapan ini dilakukan proses perancangan sistem secara keseluruhan. Perancangan tersebut terdiri dari rancangan sistem yang akan dibangun dari data yang diperoleh, hingga rancangan spesifikasi software dan hardware yang diperlukan dalam pengoperasian sistem ini. Data yang telah terkumpul dan sudah dianalisis, dapat dirancang menjadi sistem yang akan dibangun dengan menggunakan use case diagram.

- $\quad$ Implementation and Unit Testing

Tahapan ini dilakukan pengkodean aplikasi dan implementasi server. Pembuatan aplikasi dipecah menjadi modul-modul kecil yang nantinya akan digabungkan dalam tahap berikutnya. Tahapan pertama dalam pembangunan sistem ini adalah pembuatan sistem web untuk admin, setelah itu baru pembuatan untuk aplikasi android client sebagai penggunanya.

- $\quad$ Integration and System Testing

Tahapan ini, setiap unit aplikasi atau program diintegrasikan satu sama lain dan diuji sebagai satu sistem yang utuh untuk memastikan sistem sudah berfungsi dengan sesuai dan benar. Setelah itu sistem akan dikirim ke pengguna sistem.

- Operation and Maintenance

Tahapan terakhir ini, sistem diinstal dan mulai digunakan. Selain itu juga memperbaiki error yang tidak ditemukan pada tahap pembuatan. Dalam tahap ini juga dilakukan pengembangan sistem seperti penambahan fitur dan fungsi baru.

\section{HASIL DAN PEMBAHASAN}

\section{A. Data Penelitian}

Dalam proses pembangunan Sistem Informasi Geografis pemetaan hama wereng di Kabupaten Banyumas ini. Terdapat dua kebutuhan data yang digunakan dalam proses pembuatan aplikasi diantaranya data spasial dan data non-spasial. Data spasial merupakan data yang memuat tentang lokasi suatu objek dalam peta berdasarkan posisi geografis objek 
tersebut dalam Bumi dengan menggunakan koordinat, pada kasus pembuatan sistem ini data yang dimasukkan kedalam sistem adalah data yang berupa koordinat Latitude (Garis Lintang) dan Longitude (Garis Bujur). Data tersebut dapat diperoleh dengan menggunakan fasilitas dari Google Maps.

Sedangkan, untuk data keluaran data non-spasial sendiri merupakan data yang memuat karakteristik atau keterangan dari suatu objek yang terdapat dalam peta yang sama sekali tidak berkaitan berkaitan dengan posisi geografi objek tertentu. Contoh dalam kasus pembuatan sistem ini adalah berupa data seperti nama lokasi penyebaran hama wereng, jumlah sebaran keadaan serangan hama wereng, jenis hama wereng, jenis padi, dan sebagainya. Data tersebut diperoleh langsung dari Laboratorium Pengamatan Hama Tanaman dan Pangan Banyumas di Jatilawang.

\section{B. Kebutuhan Data Sistem}

\section{Kebutuhan Data Masukan (Input)}

Kebutuhan data input sistem meliputi data spasial dan data non-spasial dari masing-masing data yang diperlukan seperti lokasi sebaran hama wereng, jumlah serangan, dan lain sebagainya.

\section{Kebutuhan Data Keluaran (Output)}

Data output pada sistem ini berupa informasi data statistik jumlah sebaran hama wereng, serangan, pengendalian, serta tampilan peta hama wereng dengan koordinat lokasi atau daerah terkena dampak serangan hama wereng di Kabupaten Banyumas.

\section{Perancangan Sistem}

Kegiatan yang dilakukan dalam proses perancangan sistem adalah menentukan arsitektur sistem secara keseluruhan. Perancangan sistem melibatkan desain sistem, ini yang nantinya akan diimplementasikan. Perancangan sistem ini meliputi perancangan sistem admin dan sistem user, activity diagram system, perancangan database, dan perancangan antarmuka aplikasi.

\section{Implementasi Sistem}

Hasil perancangan aplikasi Sistem Informasi Geografis Pemetaan Hama Wereng ini kemnudian diimplementasikan untuk dua pengguna yaitu pengguna sebagai admin atau pengelola dan user sebagai pemakai dari aplikasi android client. Berikut hasil tampilan dari perancangan sistem yang telah dibuat:

\section{Aplikasi Website Admin (Pengelola) Halaman Login Aplikasi}

Halaman login merupakan halaman yang pertama kali diakses ketika akan masuk ke aplikasi web admin. Pada halaman ini terdapat form username dan password serta button masuk. Login aplikasi menggunakan akun admin yang sudah terdaftar, seperti pada Gambar 2. 


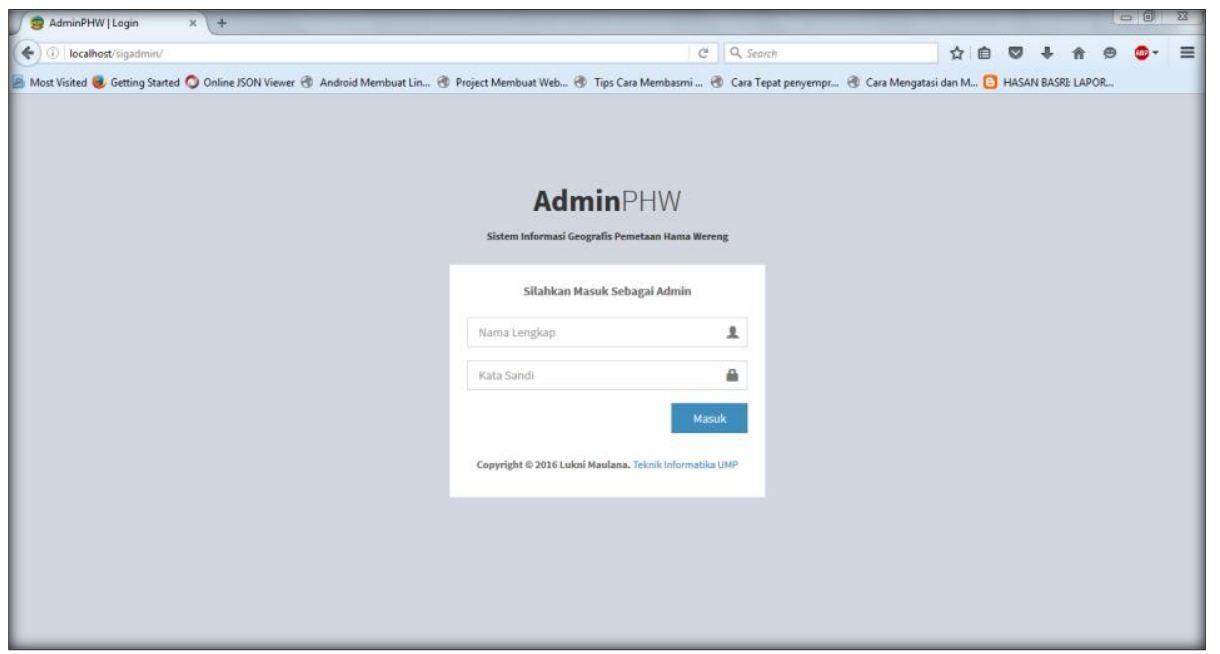

Gambar 2. Tampilan Halaman Login Aplikasi

\section{Halaman Beranda Aplikasi}

Halaman beranda ini merupakan tampilan awal aplikasi ketika sudah melakukan login dengan akun admin yang sudah terdaftar, seperti pada Gambar 3.

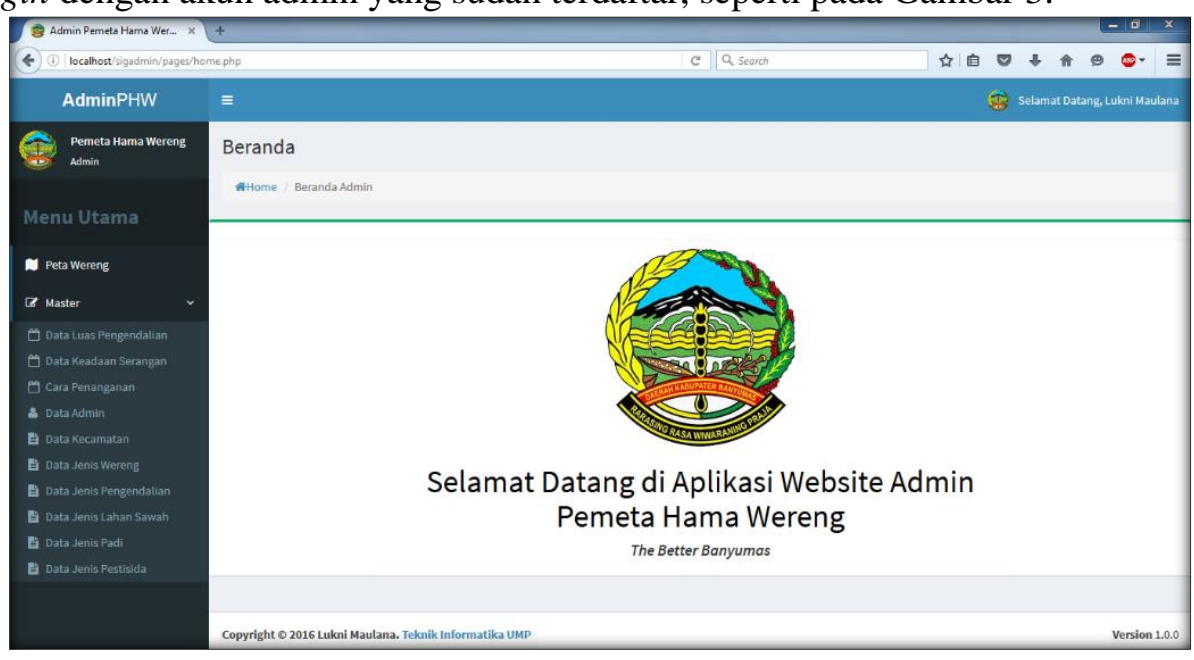

Gambar 3. Tampilan Halaman Beranda Aplikasi

\section{Halaman List Data Luas Keadaan Serangan}

Halaman ini berisi data luas keadaan serangan hama wereng di setiap Kecamatan yang mengalami dampak serangan hama wereng di Kabupaten Banyumas. Berfungsi menampilkan informasi data luas keadaan serangan wereng baik bagi pengelola (admin) maupun bagi pengguna (user), terdapat beberapa action yaitu edit data, view data, dan delete data. Serta tambah data untuk menambahkan data yang akan dimasukkan, seperti pada Gambar 4. 


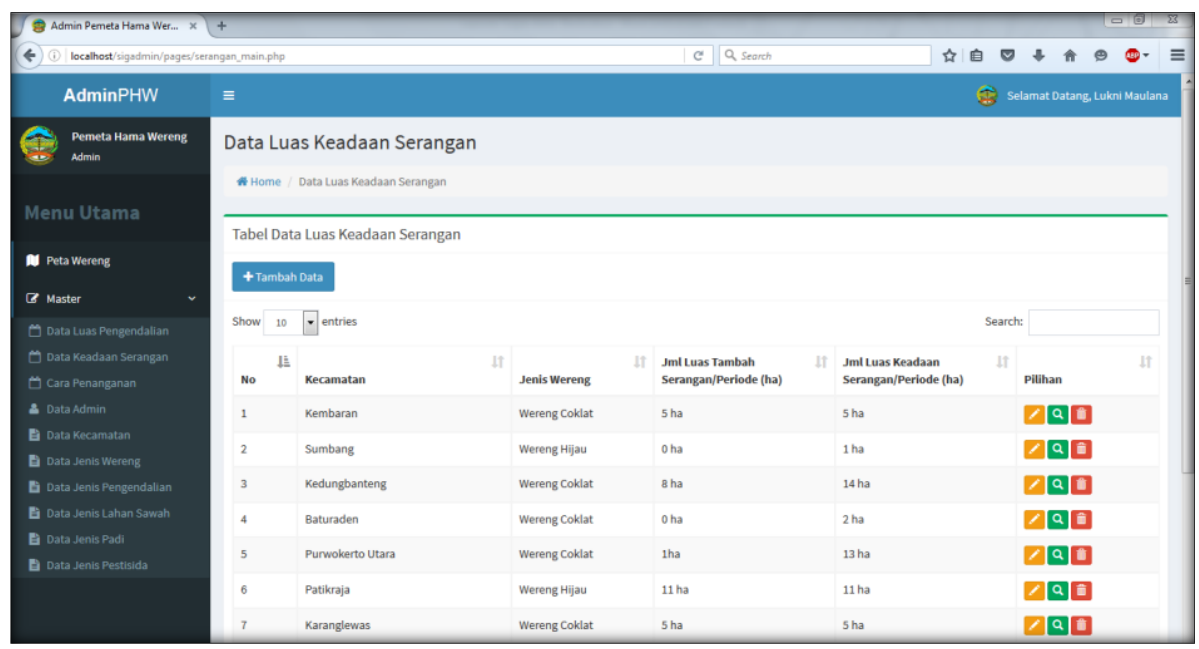

Gambar 4. Tampilan Halaman List Data Luas Keadaan Serangan

Halaman Tambah Data Luas Keadaan Serangan

Halaman ini berisi form tambah data untuk menambahkan data luas keadaan serangan hama wereng dari data laporan per kecamatan yang mengalami dampak serangan hama wereng. Data masukan berupa data spasial (koordinat latitude dan koordinat longitude) dan data non-spasial (nama, lokasi, jenis wereng, luas serangan, dan jumlah luas serangan), seperti pada Gambar 5.

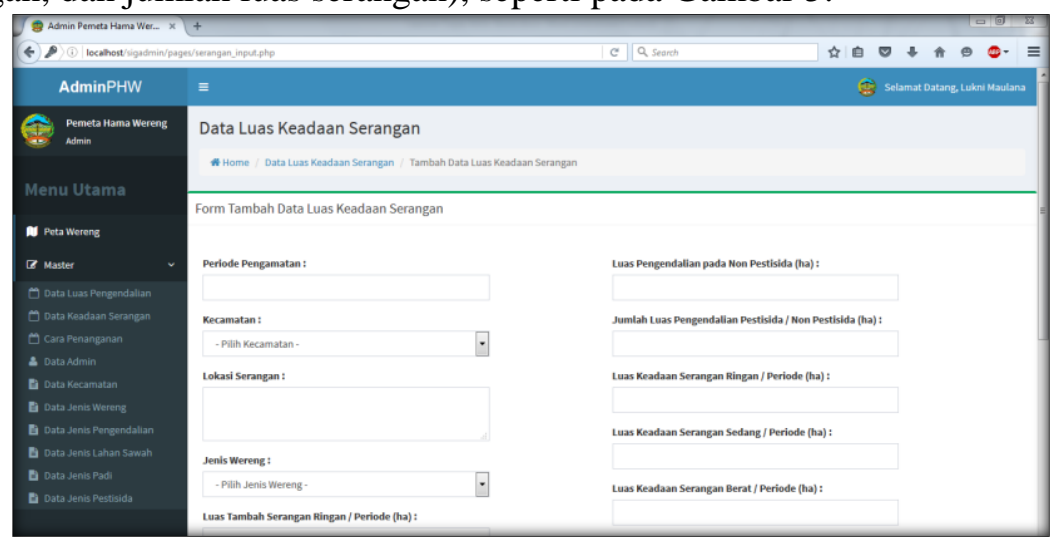

Gambar 5. Tampilan Halaman Tambah Data Luas Keadaan Serangan

\section{Halaman Ubah Data Luas Keadaan Serangan}

Halaman ini berisikan form edit data untuk merubah data luas keadaan serangan, seperti pada Gambar 6. 


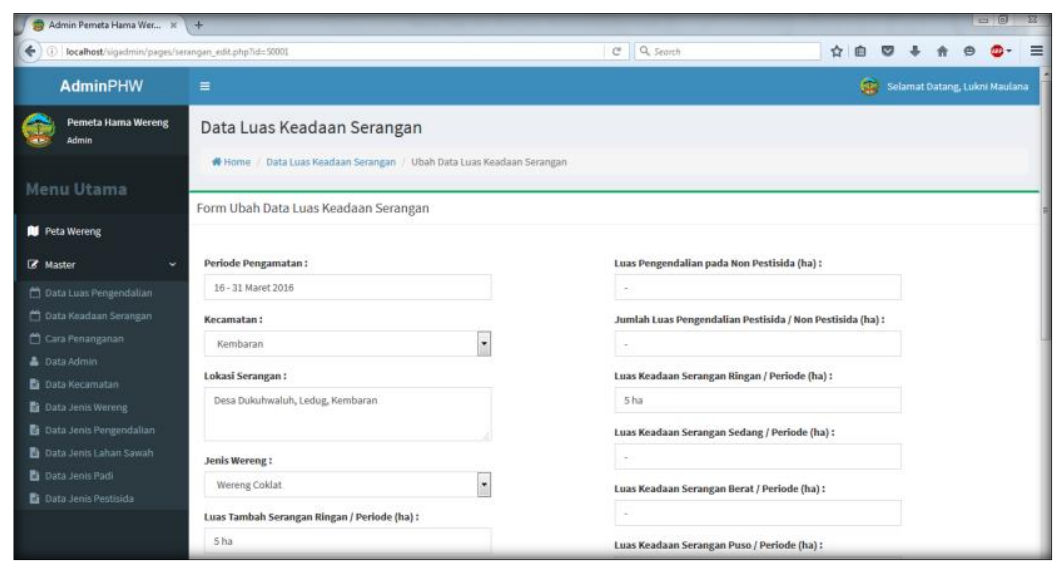

Gambar 6. Tampilan Halaman Ubah Data Luas Keadaan Serangan

\section{Halaman Detail Data Luas Keadaan Serangan}

Halaman ini berisikan form view dari data luas keadaan serangan hama wereng di Kabupaten Banyumas yang sudah dimasukkan oleh admin, seperti yang ditunjukkan pada Gambar 7.

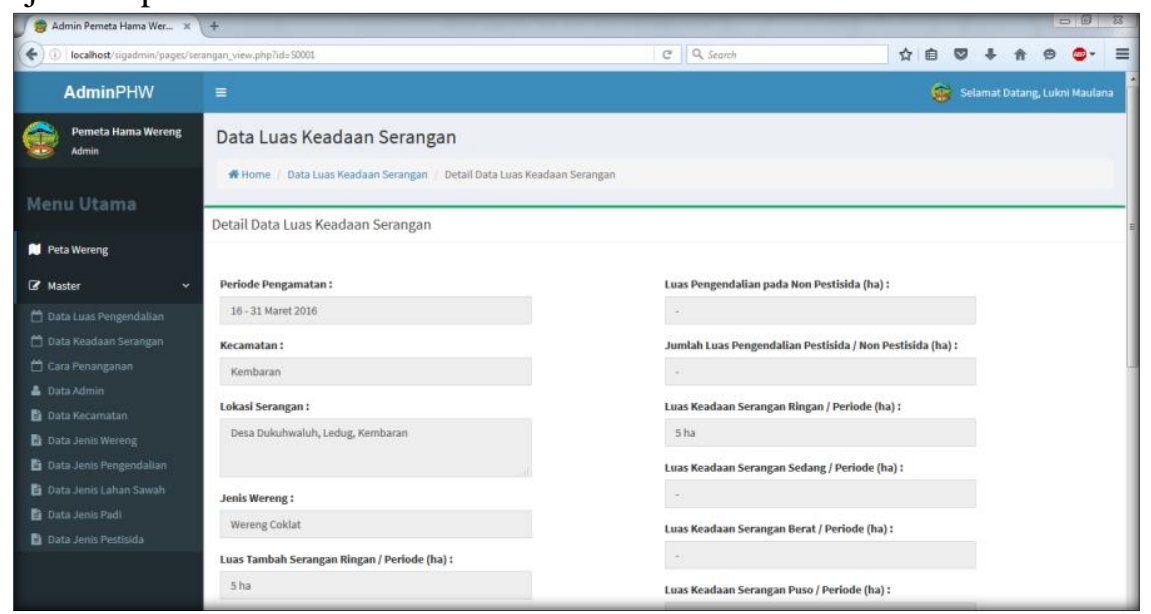

Gambar 7. Tampilan Halaman Detail Data Luas Keadaan Serangan

\section{Halaman Peta Hama Wereng}

Halaman ini berisikan tampilan peta dengan marker lokasi sebaran serangan hama wereng di setiap Kecamatan yang terkena dampak serangan wereng, seperti yang ditunjukkan pada Gambar 8. 


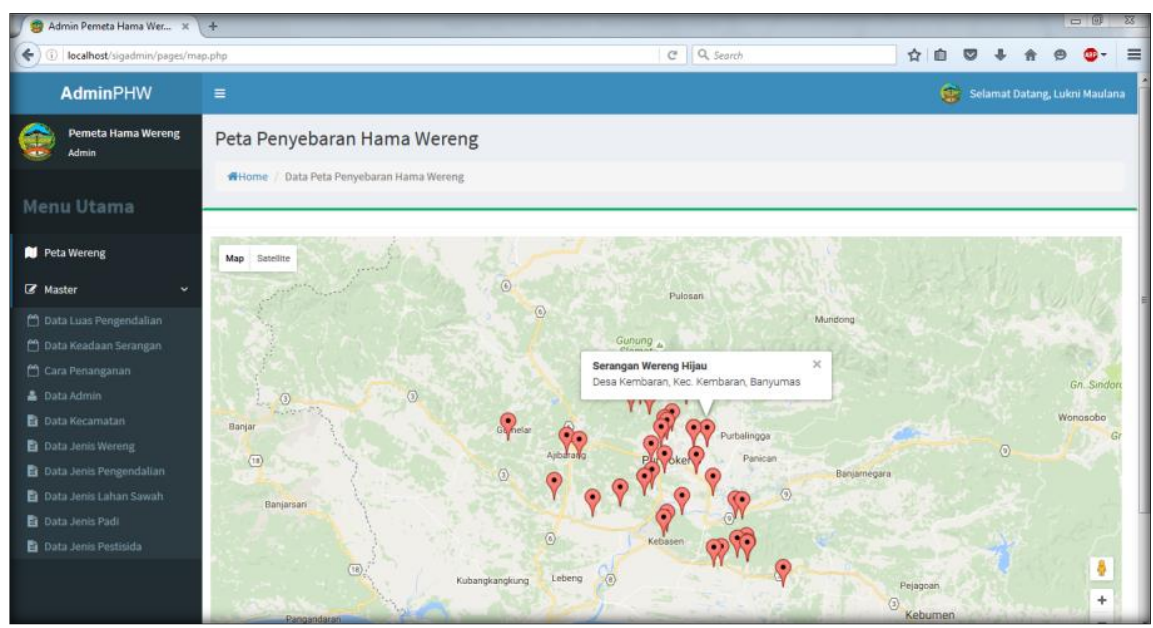

Gambar 8. Tampilan Halaman Peta Hama Wereng

Penjelasan dari Gambar 8. Setelah admin memasukan data tambah luas keadaan serangan, maka pada halaman peta hama wereng ini akan muncul tampilan peta berupa marker-marker lokasi daerah yang terkena dampak serangan wereng, berisikan informasi nama jenis wereng dan lokasi. Selain itu juga terdapat fasilitas zoom area untuk memperbesar tampilan peta dan fasilitas tampilan satellite untuk merubah tampilan peta ke mode tampilan satelit.

\section{Aplikasi Android Client (Pengguna)} Tampilan Beranda Utama Aplikasi

Halaman ini merupakan tampilan awal aplikasi setelah proses loading splash screen, berisikan tulisan selamat datang aplikasi dan logo aplikasi Banyumas, serta nama developer dan tahun pembuatan, seperti yang ditunjukkan pada Gambar 9.

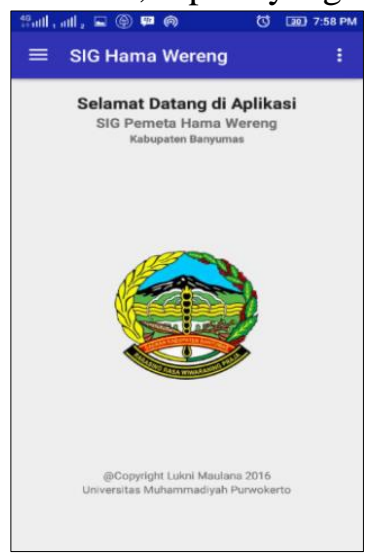

Gambar 9. Tampilan Beranda Utama Aplikasi

\section{Tampilan Menu Aplikasi}

Halaman ini berisikan menu utama dari aplikasi ini seperti menu peta hama, data serangan, data pengendalian, penanganan, kontak, dan tentang, seperti yang ditunjukkan pada Gambar 10. 


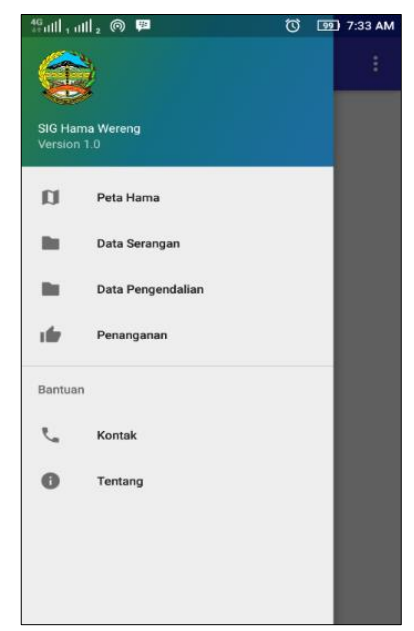

Gambar 10. Tampilan Menu Utama Aplikasi

\section{Tampilan Peta Hama Wereng}

Halaman ini berisikan tampilan peta dengan marker lokasi serangan wereng, serta terdapat fiture current location untuk menunjukan letak posisi pengguna berdasarkan GPS dari Smartphone, berfungsi untuk menampilkan letak posisi atau koordinat kecamatan yang terkena dampak serangan wereng serta sebagai penunjuk antara daerah yang terkena serangan wereng dengan yang tidak terkena dampak serangan, seperti yang ditunjukkan pada Gambar 11.

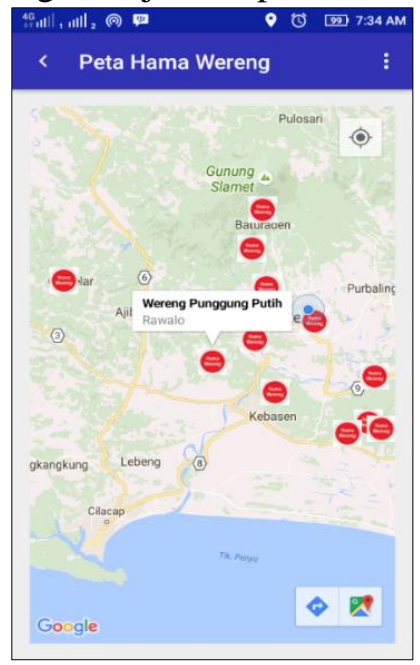

Gambar 11. Tampilan Peta Hama Wereng

\section{Tampilan Sortir Peta Hama Wereng}

Halaman ini berisikan tampilan peta hama wereng dengan sortir berdasarkan tampilan peta normal, terrain, satellite, dan hybrid, berfungsi untuk memudahkan pengguna dalam memilih tampilan peta seperti tampilan normal, terrain, satellite, dan hybrid, seperti yang ditunjukkan pada Gambar 12. 


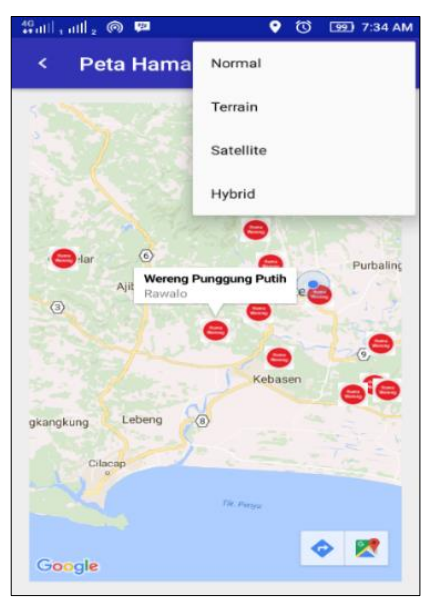

Gambar 12. Tampilan Sortir Peta Hama Wereng

\section{Tampilan Sortir Data Luas Keadaan Serangan}

Halaman ini berisikan tampilan sortir data yang berfungsi untuk mengkategorikan data berdasarkan jenis serangan wereng, ketika pengguna ingin menampilkan data berdasarkan kategori tertentu, seperti yang ditunjukkan pada Gambar 13.

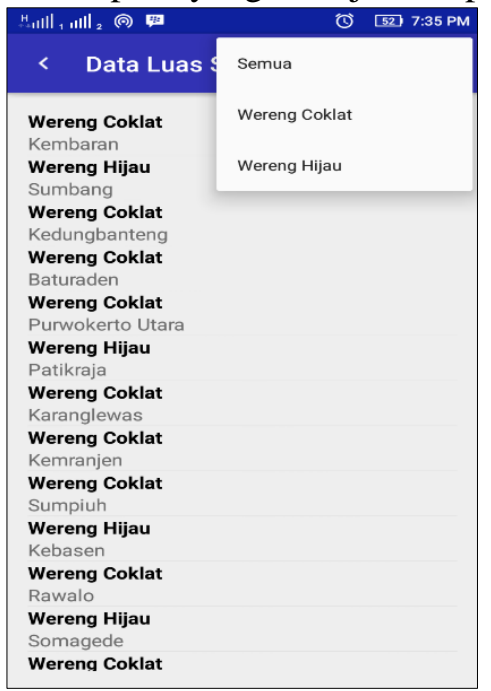

Gambar 13. Tampilan Sortir Data Luas Keadaan Serangan

\section{Tampilan Detail Luas Keadaan Serangan}

Halaman ini berisikan tampilan detail data luas keadaan serangan seperti keterangan informasi detail data dan tampilan peta lokasi, seperti yang ditunjukkan pada Gambar 14. 


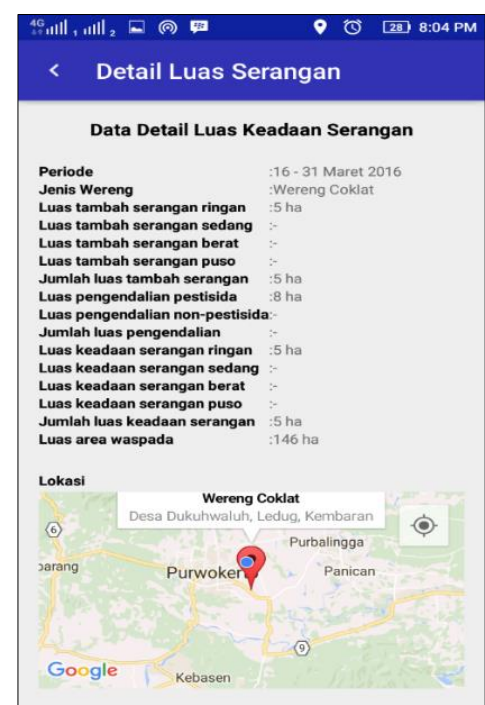

Gambar 14. Tampilan Detail Data Luas Keadaan Serangan

Penjelasan Gambar 14, setelah admin memasukan data luas keadaan serangan yang ada di aplikasi website admin maka detail data tersebut akan tampil juga di aplikasi android client tepatnya di halaman data serangan. Pada halaman ini menampilkan informasi data detail luas keadaan serangan hama wereng di setiap Kecamatan yang terkena dampak serangan wereng di Kabupaten Banyumas. Terdapat tampilan peta lokasi dengan marker lokasi daerah yang terkena serangan wereng serta fasilitas current location yang berfungsi sebagai penunjuk lokasi dimana pengguna berada.

Berdasarkan implementasi sistem dengan sasaran pengguna petugas penyuluh pertanian dan petani, didapatkan hasil bahwa Sistem Informasi Gografis ini dapat memberikan kemudahan informasi bagi para petani untuk mengetahui informasi tentang hama tanaman seperti wereng dan berbagai jenisnya, serta cara penanganannya, sekaligus memudahkan bagi patugas dari Dinas terkait untuk memperbaharui informasi seputar hama wereng dengan sistem ini.

\section{KESIMPULAN}

Berdasarkan hasil dan pembahasan, dapat disimpulkan bahwa Sistem Informasi Geografis pemetaan penyebaran daerah hama wereng di Kabupaten Banyumas ini dapat memberikan kemudahan bagi para petani untuk mengetahui informasi tentang hama tanaman seperti wereng dan cara penanganannya. Serta memudahkan bagi petugas dari Dinas terkait untuk memperbaharui informasi seputar hama wereng dengan sistem ini. Aplikasi berbasis android ini juga dapat memberikan informasi penyebaran atau populasi wereng. Serta memudahkan Lembaga atau Dinas yang terkait dapat mengetahui informasi pemetaan penyebaran hama wereng pada tanaman padi di Kabupaten Banyumas.

\section{DAFTAR PUSTAKA}

Agung, G. (2015). Mengenal Dasar-dasar Pemrograman Android. Jakarta: PT Elex

Media Komputindo.

Mustafidah, H., \& Suwarsito, S. (2020). Dasar-Dasar Metodologi Penelitian.

Purwokerto: UM Purwokerto Press.

Riyanto. (2010). Sistem Informasi Geografis Berbasis Mobile. Yogyakarta: Gava Media. 
Rukmana, R., \& UU Sugandi, S. (1997). Hama Tanaman dan Teknik Pengendalian. Yogyakarta: Kanisius.

Soemadi, W. (1997). Pengendalian Hama Tanaman Pangan. Solo: CV. ANEKA.

Sommerville, I. (2011). Software Engineering Ninth Edition. Boston: Pearson. 